\title{
Synapsin I in PC12 Cells. I. Characterization of the Phosphoprotein and Effect of Chronic NGF Treatment
}

\author{
Carmelo Romano, Robert A. Nichols, Paul Greengard, and Lloyd A. Greene \\ Laboratory of Molecular and Cellular Neuroscience, Rockefeller University, New York, New York 10021; and Department \\ of Pharmacology, New York University School of Medicine, New York, New York 10016
}

\begin{abstract}
PC12 cells contain a synapsin I-like molecule. Several serum and monoclonal antibodies raised against bovine brain synapsin I bind to and precipitate this molecule, demonstrating immunochemical similarity between the brain and PC12 species. PC12 synapsin I, like brain synapsin I, is a phosphoprotein: It is phosphorylated in intact cells and, when partially purified, serves as a substrate for several synapsin I kinases. PC12 cell synapsin I is structurally similar to brain synapsin I as shown by peptide mapping of ${ }^{35}$ S-methionineand ${ }^{32}$-phosphate-labeled molecules from the 2 sources. Chronic NGF treatment of the cells induces a significant increase in the amount of synapsin I relative to total cell protein, measured either by immunolabeling or incorporation of ${ }^{35} \mathrm{~S}$-methionine. The synapsin I present in untreated $\mathrm{PC} 12$ cells migrates predominantly as a singlet and that present in cells treated chronically with NGF as a doublet in SDSPAGE.
\end{abstract}

Synapsin I is a phosphoprotein present in virtually all neurons, where it is found in association with small synaptic vesicles (DeCamilli et al., 1983a, b; Huttner et al., 1983; Navone et al., 1984). The phosphorylation of synapsin $I$ is regulated by neuronal activity. For example, stimulation of neuronal preparations by neurotransmitters (Nestler and Greengard, 1980; Dolphin and Greengard, 1981; Tsou and Greengard, 1982; Mobley and Greengard, 1985) or by impulse conduction at physiological frequencies (Nestler and Greengard, 1982) causes marked, reversible increases in the state of phosphorylation of synapsin I. The appearance of synapsin I during development correlates with synapse formation (Lohmann et al., 1978). In vitro translation reactions directed by polysomes isolated from developing rat brain have shown that the synthesis of synapsin I is greatest at the time of maximal synaptogenesis (DeGennaro et al., 1983).

$\mathrm{PC} 12$ is a clonal cell line derived from a rat pheochromocytoma (Greene and Tischler, 1976). When cultured in the presence of NGF for several days, these cells become electrically excitable, grow long branching neurites, and undergo several biochemical changes (Greene and Tischler, 1982). They have therefore proved useful as a model system for the study of NGF action on the developing neuron.

Received Jan. 31, 1986; revised Oct. 28, 1986; accepted Dec. 15, 1986.

This work was supported in part by grants (NS-21550 and MH-39327) to P.G. and (NS-16036) to L.A.G. C.R. was an NIH postdoctoral fellow (NS06778). R.A.N. was a Muscular Dystrophy Association postdoctoral fellow.

Correspondence should be addressed to Dr. Carmelo Romano, Department of Pharmacology, University of Pennsylvania, 36th Street and Hamilton Walk, Philadelphia, PA 19104

Copyright $\odot 1987$ Society for Neuroscience $0270-6474 / 87 / 051294-06 \$ 02.00 / 0$
Adrenal chromaffin cells and sympathetic neurons share a neural crest origin and many other similarities (Coupland, 1965; Weston, 1970). Nevertheless, normal rat adrenal chromaffin cells do not, whereas sympathetic neurons do, contain synapsin I (DeCamilli et al., 1979; Fried et al., 1982). To better understand the developmental regulation of synapsin I, it was therefore of interest to study synapsin I in PC12 cells and its possible alteration upon treatment of the cells with NGF. This paper characterizes the synapsin I present in PC12 cells and demonstrates effects of long-term NGF treatment of the cells on the phosphoprotein. The accompanying paper (Romano et al., 1987) demonstrates that short-term NGF treatment of PC12 cells results in the phosphorylation of synapsin I at a novel site. Some of the results have been briefly presented elsewhere (Romano et al., 1984).

\section{Materials and Methods}

Cell culture. In some experiments, $\mathrm{PC} 12$ cells were grown as described (Greene and Tischler, 1976, 1982) in medium consisting of 85\% RPMI 1640 medium, $5 \%$ fetal bovine serum, and $10 \%$ heat-inactivated horse serum (KC. Biologicals). In other experiments, PC12 cells were grown in $85 \%$ Dulbecco's modified Eagle's medium (DMEM), 10\% fetal bovine serum, and $5 \%$ heat-inactivated horse serum. Cells were maintained on tissue culture plastic, at $37^{\circ} \mathrm{C}$, in a humidified atmosphere of $95 \%$ air, $5 \% \mathrm{CO}_{2}$. For experiments requiring exposure to $\mathrm{NGF}$, cells were grown on collagen-coated dishes (rat-tail tendon collagen, prepared by the method of Bornstein, 1958). One rat tail provided $250 \mathrm{ml}$ of collagen solution, and 1 drop was used per $35-\mathrm{mm}$ dish. The medium for these experiments contained either $2.5 \mathrm{~S} \mathrm{NGF}(50 \mathrm{ng} / \mathrm{ml})$ prepared from adult male mouse submaxillary glands as described by Mobley et al. (1976) or $7 \mathrm{~S} \mathrm{NGF}(0.25 \mu \mathrm{g} / \mathrm{ml})$ prepared from adult male mouse saliva (Burton et al., 1978), and was changed every third day.

Labeling of cells. Cultures were washed twice with HEPES-buffered saline (HBS: HEPES, $25 \mathrm{~mm} ; \mathrm{NaCl}, 154 \mathrm{~mm} ; \mathrm{KCl}, 5.6 \mathrm{~mm} ; \mathrm{CaCl}_{2}, 2.0$ $\left.\mathrm{mm} ; \mathrm{MgCl}_{2}, 1.0 \mathrm{~mm}\right)$. Total cellular proteins were then labeled by incubation for $1 \mathrm{hr}$ in a humidified atmosphere at $37^{\circ} \mathrm{C}$ with either ${ }^{35} \mathrm{~S}$ methionine (specific activity; $1300 \mathrm{Ci} / \mathrm{mmol}$; Amersham) at $0.05-0.2$ $\mathrm{mCi} / \mathrm{ml}$ in DMEM prepared free of methionine or with ${ }^{32} \mathrm{P}$-phosphoric acid (carrier-free; New England Nuclear) at $0.5 \mathrm{mCi} / \mathrm{ml}$ in DMEM prepared free of phosphate. After removal of the labeling medium, the cells were rinsed with ice-cold HBS and then taken up in $1 \%$ SDS. The solubilized extract was boiled, sonicated, and either processed immediately for immunoprecipitation or stored frozen at $-20^{\circ} \mathrm{C}$.

Immunoprecipitation. Because synapsin $\mathrm{I}$ is not an abundant protein in $\mathrm{PC} 12$ cells, a highly specific, "2-cycle" immunoprecipitation procedure was developed to purify it sufficiently for analysis. SDS-solubilized, labeled extracts were added to an equal volume of NET buffer (NET: NaCl, $200 \mathrm{~mm}$; EDTA, $10 \mathrm{~mm}$; Tris, $100 \mathrm{~mm}$; pH 7.4) containing the nonionic detergent Non-idet P40 (NP40) at 5\% (vol/vol) and 100 $\mathrm{mm} \mathrm{NaF}$. The final volume was usually $1 \mathrm{ml}$. Excess serum or monoclonal antibody raised against bovine brain synapsin I was added. After $30 \mathrm{~min}, 100 \mu \mathrm{l}$ of a $10 \%$ suspension of protein A-bearing Staphylococcus aureus cells (Pansorbin, Calbiochem) in NET buffer, containing 1\% $\mathrm{NP} 40$ and $25 \mathrm{mg} / \mathrm{ml} \mathrm{BSA}$, was added, and the incubation continued 


\section{$\mathrm{PC} \mathrm{Br}$}

\section{synapsin I}

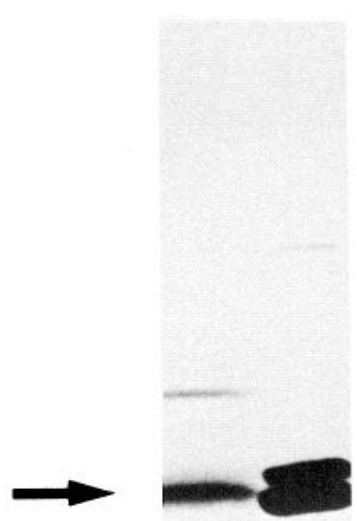

Figure 1. Comparison of brain and PC12 synapsin I by immunolabeling of a gel transfer. The SDS-PAGE samples contained $525 \mu \mathrm{g}$ of $\mathrm{PC} 12$ cell protein (left) or $50 \mu \mathrm{g}$ of rat brain protein (right). for another $30 \mathrm{~min}$. The suspension was microfuged and the supernatant discarded. The pellet was resuspended in $0.5 \mathrm{ml}$ of $1 \%$ SDS (resuspension was aided by gentle probe sonication). This disrupted the antigenantibody-protein A interactions, irreversibly denatured the antibody, and resolubilized the partially purified synapsin I. The suspension was microfuged and the supernatant added to an equal volume of NET buffer containing detergent and fluoride as above. Antibody was added, and the immunoprecipitation repeated. The pellet from this second cycle of immunoprecipitation was washed once in NET buffer, suspended in SDS-PAGE sample buffer, boiled, and microfuged; the supernatant was analyzed by SDS-PAGE according to Laemmli (1970) in $7.5 \%$ polyacrylamide gels. All of the above steps were carried out at room temperature. Control experiments were performed in which addition of radiolabeled bovine brain synapsin I to unlabeled PC1 2 cell SDS homogenates and immunoprecipitation by the 2-cycle procedure resulted in a final recovery of $80-85 \%$. The amount of endogenously labeled PC12 synapsin I recovered was linear with the amount of extract added, indicating quantitative precipitations.

Quantitation of in situ-labeled synapsin I. Dried gels that had been treated with EN $^{3}$ HANCE (New England Nuclear) were exposed to Kodak XAR film "flashed" according to Laskey and Mills (1975) to increase sensitivity. Protein bands were quantitated either by cutting them out of the dried gel using the autoradiogram as a guide and counting in a liquid scintillation spectrometer or by densitometry with a Zeineh scanning densitometer using visible light and determining peak area by cutting and weighing. The 2 methods gave equivalent results.

Peptide mapping. Peptide mapping after limited proteolysis with Staphylococcus aureus protease was performed in $15 \%$ polyacrylamide gels according to Cleveland et al. (1977) as modified by Huttner and Greengard (1979).

Immunolabeling of gel transfers. Proteins were electrophoretically transferred from polyacrylamide gels to nitrocellulose sheets $(S \& S, 0.2$ $\mu \mathrm{m}$ pore size) at $20 \mathrm{~V}$ for $4-6 \mathrm{hr}$ by the method of Towbin et al. (1979). In the standard procedure, the sheets were then processed as follows: (1) fixation in isopropanol/acetic acid/water (25:10:65, vol/vol/vol), 15 min; (2) washing with several changes of water over $15 \mathrm{~min}$; (3) incubating in a wash buffer [ $20 \mathrm{~mm}$ sodium phosphate, $100 \mathrm{~mm}$ sodium chloride, $\mathrm{pH} 7.4$, containing $0.1 \%$ Tween-20 to block nonspecific adsorption of proteins to the nitrocellulose (Batteiger et al., 1982)], 30 min; (4) incubating in a 250:1 dilution of antibody in wash buffer, 60 min; (5) washing out antibody with several changes of wash buffer, over methionine

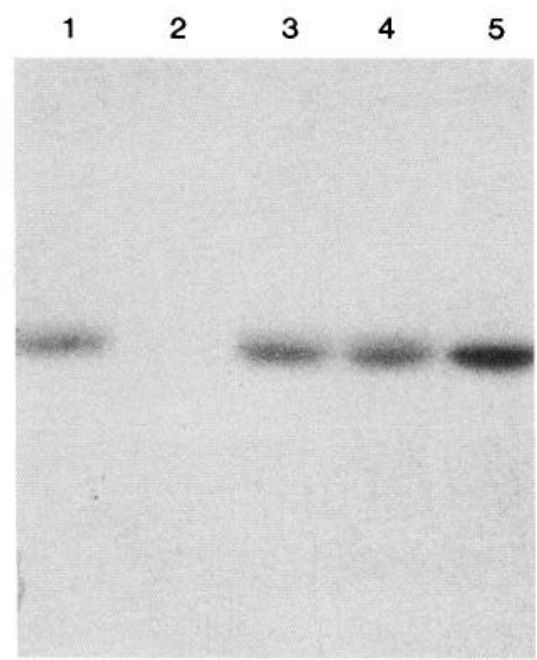

phosphate

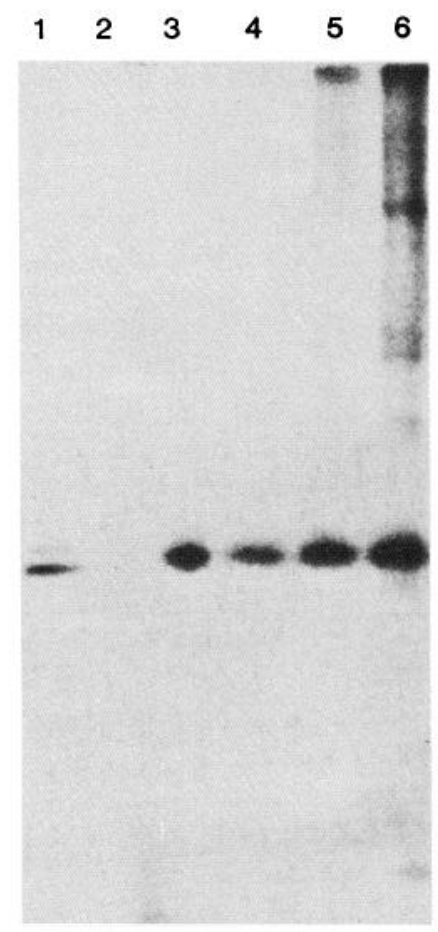

Figure 2. Immunological characterization of $\mathrm{PC} 12$ synapsin I. Left, $\mathrm{PC1} 2$ cells were incubated in medium containing ${ }^{35} \mathrm{~S}$-methionine for $1 \mathrm{hr}$ and then solubilized in $1 \%$ SDS. Immunoprecipitation of ${ }^{35} \mathrm{~S}$-methionine-labeled synapsin I from these homogenates was performed using various polyclonal rabbit (lanes 1-4) or monoclonal mouse (lane 5) antibodies raised against purified bovine brain synapsin I. In lane 2 , excess pure bovine synapsin I, purified according to Ueda and Greengard (1977), was present during the immunoprecipitation. Right, PC12 cells were incubated in medium containing ${ }^{32} \mathrm{P}$ phosphate for $1 \mathrm{hr}$ and then solubilized in $1 \%$ SDS. Immunoprecipitation was performed using several polyclonal rabbit antibodies (lanes 3-6) or normal rabbit serum (lane 2). Lane 1 contains phosphorylated rat brain synapsin I as standard. 
methionine

Figure 3. Comparison of partial proteolysis products of synapsin I from rat brain and PC12 cells. Peptide mapping using $5 \mu \mathrm{g} S$. aureus protease according to the method of Cleveland et al. (1977) was performed on the following preparations. Left, ${ }^{35} \mathrm{~S}$-methionine-labeled synapsin I purified from in vitro translation products of rat brain polysomes $(B)$ or from labeled $\mathrm{PC} 12$ cell homogenates $(P C)$ by immunoprecipitation followed by SDS-PAGE (translation products kindly provided by Dr. S. Kanazir). Right, ${ }^{32} \mathrm{P}$-phosphate-labeled synapsin I purified from labeled PC12 cell homogenates $(P C, P C C)$ or from a neutralized acid extract of rat cortical protein that had been incubated with $\gamma-{ }^{32} \mathrm{P}-\mathrm{ATP}$ and a high concentration of the purified catalytic subunit of cyclic AMP-dependent protein kinase $(B)$ by immunoprecipitation followed by SDSPAGE. Excess unlabeled pure bovine synapsin I was present during the immunoprecipitation shown in lane PCc. The positions of the $35 \mathrm{kDa}$ (upper) and the $10 \mathrm{kDa}$ (lower) phosphopeptides previously described for limited $S$. aureus proteolysis of rat brain synapsin I (Huttner and Greengard, 1979) are as indicated. Residual intact synapsin I does not effectively migrate out of the gel piece and into the second gel.

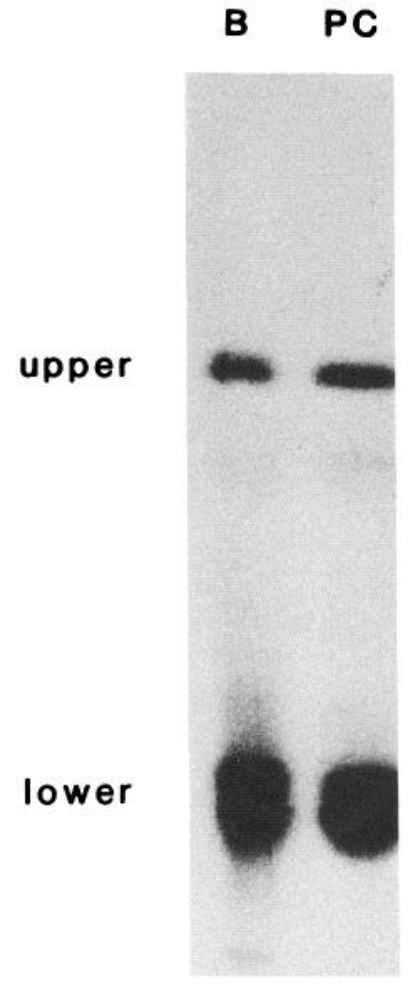

phosphate

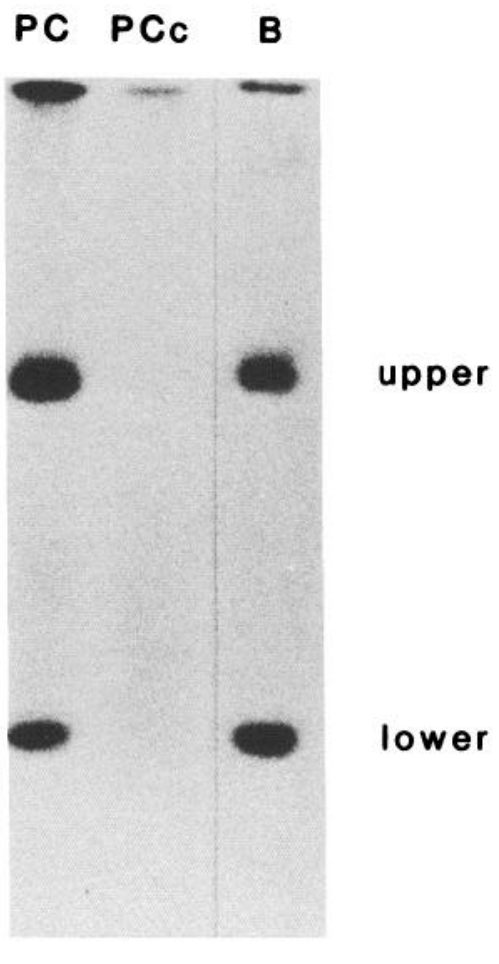

$60 \mathrm{~min}$; (6) incubating in a 3000:1 dilution of affinity-purified goat antirabbit IgG coupled to HRP (Bio-Rad) in wash buffer, $60 \mathrm{~min}$; (7) washing out antibody with several changes of wash buffer followed by several changes using wash buffer without Tween-20, over $60 \mathrm{~min}$; (8) incubating in peroxidase substrate solution [ $50 \mathrm{ml}$ wash buffer without Tween$20,10 \mathrm{ml}$ of $3 \mathrm{mg} / \mathrm{ml} \mathrm{6}$-chloronaphthol in methanol, $0.1 \mathrm{ml} 30 \%$ hydrogen peroxide (Towbin et al., 1979)], $60 \mathrm{~min}$. Developed sheets were washed in water, wrapped in plastic wrap, and stored in the dark.

\section{Results}

Characterization of synapsin I from PC12 cells

$\mathrm{PC} 12$ cells contain a molecule that cross-reacts with antiserum raised against bovine brain synapsin I (Fig. 1). The concentration of this molecule in PC12 cells is lower than that of synapsin I in rat brain: Roughly an order of magnitude less brain protein provides a comparable signal by this immunolabeling technique. The molecules from brain and PC12 cells are qualitatively different. Brain synapsin I can be resolved as a discrete doublet composed of synapsin Ia and synapsin Ib; the PC12 molecule is a heterogenous species (see Romano et al., 1987, Figs. 1 and 2) whose predominant member is a singlet (Fig. 1) having a mobility between that of brain synapsin Ia and of synapsin Ib.

All serum and monoclonal antibodies against bovine brain synapsin I that have been tested provided the same pattern of immunolabeling in gel transfers as that shown in Figure 1 and precipitated the molecule from ${ }^{35} \mathrm{~S}$-methionine-labeled $\mathrm{PC} 12$ cell SDS homogenates (Fig. 2, left). This precipitation was specifically prevented when excess unlabeled bovine brain synapsin I was present during the antibody incubation. These data indicate that the PC12 cell synapsin I-like molecule is closely related immunologically to brain synapsin I, and we shall henceforth refer to it as "PC12 synapsin I."

$\mathrm{PC} 12$ synapsin I is a phosphoprotein, as shown by immunoprecipitation from SDS-homogenates of ${ }^{32} \mathrm{P}$-phosphate-labeled PC12 cells (Fig. 2, right). All serum and monoclonal antibodies against bovine brain synapsin I that have been tested precipitated the phosphoprotein.

Synapsin I from mammalian brain is nearly quantitatively extracted by $11 \mathrm{~mm}$ citric acid (Forn and Greengard, 1978). Similarly, when ${ }^{35} \mathrm{~S}-$ methionine-labelled $\mathrm{PC} 12$ cells were homogenized in $11 \mathrm{~mm}$ citric acid, the immunoprecipitable synapsin I was nearly quantitatively extracted.

Limited protolysis mapping (Huttner and Greengard, 1979) demonstrated structural similarities between rat brain and PC12 synapsin I (Fig. 3). This was seen in both the ${ }^{35} \mathrm{~S}$-methioninelabeled molecules and the ${ }^{32} \mathrm{P}$-phosphate-labeled molecules.

Data presented in the accompanying paper (Romano et al., 1987) demonstrate that partially purified $\mathrm{PC} 12$ synapsin I, like rat brain synapsin I, can be phosphorylated by purified cyclic AMP-dependent protein kinase, calcium/calmodulin-dependent protein kinase I, calcium/calmodulin-dependent protein kinase II, and protein kinase C. Two-dimensional phosphopeptide fingerprint analysis of brain and PC12 synapsin I, phosphorylated by any one of these purified kinases, showed nearly identical patterns of phosphopeptides (Romano et al., 1987, Fig. 9). This is further evidence of the extensive structural homology between brain and $\mathrm{PC} 12$ synapsin $\mathrm{I}$.

Glucocorticoids are essential for the normal development of chromaffin cells. For example, they are responsible for the main- 


\section{NGF $\quad 0 d \quad 14 d$}

\section{synapsin I $\rightarrow$}

tenance of the expression of phenylethanolamine $N$-methyl transferase, the epinephrine-synthesizing enzyme. Glucocorticoids did not alter the rate of synthesis of synapsin I in PC12 cells. Comparable amounts of synapsin I were synthesized by control cells and those grown with dexamethasone, corticosterone, hydrocortisone, or triamcinolone, each present at $10 \mu \mathrm{M}$, for periods of up to a week (data not shown).

\section{Effect of chronic treatment with $N G F$}

A comparison of synapsin I in control PC12 cells with that in PC1 2 cells treated with NGF for long periods revealed differences in amount, rate of synthesis, and electrophoretic mobility. Relative to total cell protein, the treated cells contained more synapsin I, and it behaved as a doublet on SDS-PAGE (Fig. 4). The increase in specific levels of immunoreactive PC12 synapsin I began after a lag of $2 \mathrm{~d}$ and after 2 weeks of exposure to NGF, reached a plateau 3-fold greater than the basal level (Fig. 5). Levels of synapsin I in untreated PC12 cells were independent of cell density or culture age (data not shown).

Exposure of PC12 cells to NGF for $14 \mathrm{~d}$, but not for $1 \mathrm{~d}$, caused an apparent increase of 1.8-fold in the rate of synthesis of synapsin I relative to total cell protein (data not shown). It
Figure 4. Effect of long-term exposure of cells to NGF on the level and nature of PC12 synapsin I. The SDS-PAGE samples contained $525 \mu \mathrm{g}$ of control $\mathrm{PC} 12$ cell protein $(0 d)$ or $525 \mu \mathrm{g}$ of protein from $\mathrm{PCl} 2$ cells grown in the presence of NGF for 14 days (14d). Synapsin I was visualized by immunolabeling of a gel transfer. remains to be determined whether NGF
degradation of synapsin I in PC12 cells.

\section{Discussion}

Although synapsin I is present in virtually all neurons, it does not appear to be present in normal adult rat adrenal chromaffin cells (DeCamilli et al., 1979; Fried et al., 1982). Moreover, in the present study, no synapsin I was found in extracts of adrenal glands from newborn or adult rats that were labeled in organ culture for several hours in the presence of ${ }^{35} \mathrm{~S}$-methionine (unpublished observations). Since PC12 cells are derived from a rat chromaffin cell tumor (Greene and Tischler, 1976), the presence of synapsin I in untreated PC12 cells was not expected. Protein IIIa, which is related immunologically to synapsin I and which has an electrophoretic mobility on SDS-PAGE similar to synapsin I (Browning and Greengard, 1984), is known to be present in normal adult rat adrenal chromaffin cells. For these reasons, a careful characterization of the synapsin I-like protein found in $\mathrm{PC} 12$ cells was required.

By immunological criteria, PC12 synapsin I is much more closely related to authentic neuronal synapsin I than to protein III. All antibodies against brain synapsin I precipitated PC12 


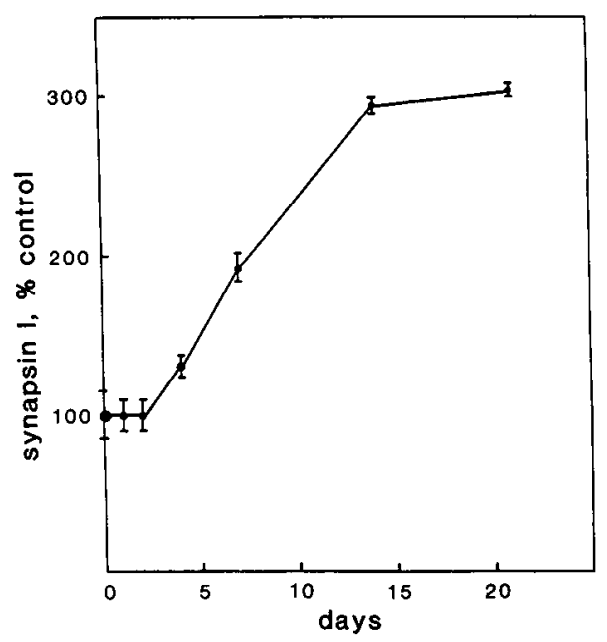

Figure 5. Effect of NGF on the amount of synapsin I in PC12 cells. The amount of synapsin I in PC12 cells is shown as a function of the number of days of exposure of cells to NGF. Quantitation was by densitometry of immunolabeled gel transfer of the type shown in Figure 4. Values are means $\pm \operatorname{SEM}(n=3)$.

synapsin I, including a monoclonal antibody that shows little, if any, cross-reactivity with brain protein III (Fig. 2, left, lane 5 , and unpublished observations). In contrast, antibodies raised against brain protein III did precipitate a distinct protein IIIalike molecule from PC12 cells (data not shown, but see accompanying paper, Fig. 1).

In addition to its immunochemical cross-reactivity, $\mathrm{PC} 12$ synapsin I is similar to brain synapsin I by several chemical criteria. Both were phosphorylated in intact preparations upon labeling with ${ }^{32} \mathrm{P}$-phosphate (present results; Krueger et al., 1977). Both were acid extractable (present results; Forn and Greengard, 1978). Finally, the 2 yielded nearly identical proteolytic products. This near identity was found whether the molecules were labeled either biosynthetically at methionine residues or by phosphorylation. These data provide strong evidence for extensive structural homology between the brain and PC12 cell molecules.

Treatment of PC1 2 cells with NGF for 2 weeks caused a 3-fold increase in the amount of synapsin I above control. The concentrations of several other molecules are known to undergo increases of similar magnitude over this time course (Greene et al., 1983; Salton et al., 1983). Extensive morphological changes also occur with this time course, including neurite extension and the appearance of clear synaptic vesicles (Tischlcr and Greene, 1978). Synapsin I appears to be exclusively associated with small clear vesicles even in nerve terminals where these organelles coexist with large dense-core neurosecretory granules (Navone et al., 1984). Electron-microscopic immunocytochemical studies will be necessary to establish the subcellular localization of PC12 synapsin I.

\section{References}

Batteiger, B., W. J. Newhall, V. Jones, and R. B. Jones (1982) The use of Tween 20 as a blocking agent in the immunological detection of proteins transferred to nitrocellulose membranes. J. Immunol. Methods 55: 297-307.

Bornstein, M. B. (1958) Reconstituted rat-tail collagen used as a substrate for tissue cultures on coverslips in Maximow slides and roller tubes. Lab. Invest. 7: 134-137.

Browning, M. D., and P. Greengard (1984) A family of synaptic ves- icle-associated phosphoproteins: Synapsin Ia, synapsin Ib, protein IIIa, and protein IIIb. Soc. Neurosci. Abstr. 10: 196.

Burton, L. E., W. H. Wilson, and E. M. Shooter (1978) Nerve growth factor in mouse saliva. J. Biol. Chem. 253: 7807-7812.

Cleveland, D. W., S. G. Fischer, M. W. Kirschner, and U. K. Laemmli (1977) Peptide mapping by limited proteolysis in sodium dodecyl sulfate and analysis by gel electrophoresis. J. Biol. Chem. 252: 11021106.

Coupland, B. (1965) The Natural History of the Chromaffin Cells, Longmans, Green, London.

DeCamilli, P., T. Ueda, F. E. Bloom, E. Battenberg, and P. Greengard (1979) Widespread distribution of protein $I$ in the central and peripheral nervous systems. Proc. Natl. Acad. Sci. USA 76: 5977-5981.

DeCamilli, P., R. Cameron, and P. Greengard (1983a) Synapsin I (protein I), a nerve terminal-specific phosphoprotein. I. Its general distribution in synapses of the central and peripheral nervous system demonstrated by immunofluorescence in frozen and plastic sections. J. Cell Biol. 96: 1337-1354.

DeCamilli, P., S. M. Harris, Jr., W. B. Huttner, and P. Greengard (1983b) Synapsin I (protein I), a nerve terminal-specific phosphoprotein. Il. Its specific association with synaptic vesicles demonstrated by immunocytochemistry in agarose-embedded synaptosomes. J. Cell Biol. 96: 1355-1373.

DeGennaro, L. J., S. D. Kanazir, W. C. Wallace, R. M. Lewis, and P. Greengard (1983) Neuron-specific phosphoproteins as models for neuronal gene expression. Cold Spring Harbor Symp. Quant. Biol. 48: 337-345.

Dolphin, A. C., and P. Greengard (1981) Neurotransmitter- and neuromodulator-dependent alterations in phosphorylation of protein I in slices of rat facial nucleus. J. Neurosci. 1: 192-203.

Forn, J., and P. Greengard (1978) Depolarizing agents and cyclic nucleotides regulate the phosphorylation of specific neuronal proteins in rat cortical slices. Proc. Natl. Acad. Sci. USA 75: 5195-5199.

Fried, G., E. J. Nestler, P. DeCamilli, L. Stjarne, L. Olson, J. M. Lundberg, T. Hökfelt, C. C. Ouimet, and P. Greengard (1982) Cellular and subcellular localization of protein $I$ in the peripheral nervous system. Proc. Natl. Acad. Sci. USA 79: 2717-2721.

Greene, L. A., and A. S. Tischler (1976) Establishment of a noradrenergic clonal line of rat adrenal pheochromocytoma cells which respond to nerve growth factor. Proc. Natl. Acad. Sci. USA 73: 24242428.

Greene, L. A., and A. S. Tischler (1982) PC12 pheochromocytoma cultures in neurobiological research. Adv. Cell. Neurobiol. 3: 373414.

Greene, L. A., R. K. H. Liem, and M. L. Shelanski (1983) Regulation of a high molecular weight microtuble-associated protein in $\mathrm{PC} 12$ cells by nerve growth factor. J. Cell Biol. 96: 76-83.

Huttner, W. B., and P. Greengard (1979) Multiple phosphorylation sites in protein I and their differential regulation by cyclic AMP and calcium. Proc. Natl. Acad. Sci. USA 76: 5402-5406.

Huttner, W. B., W. Schiebler, P. Greengard, and P. DeCamilli (1983) Synapsin I (protein I), a nerve terminal-specific phosphoprotein. III. Its association with synaptic vesicles studied in a highly purified synaptic vesicle preparation. I. Cell Biol. 96: 1374-1388.

Krueger, B. K., J. Forn, and P. Greengard (1977) Depolarizationinduced phosphorylation of specific proteins mediated by calcium ion influx in rat brain synaptosomes. J. Biol. Chem. 252: 2764-2773.

Laemmli, U. K. (1970) Cleavage of structural proteins during assembly of the head of bacteriophage T4. Nature 227: 680-685.

Laskey, R. A., and A. D. Mills (1975) Quantitative film detection of ${ }^{3} \mathrm{H}$ and ${ }^{14} \mathrm{C}$ in polyacrylamide gels by fluorography. Eur. J. Biochem. 56: 335-341.

Lohmann, S. M., T. Ueda, and P. Greengard (1978) Ontogeny of synaptic phosphoproteins in brain. Proc. Natl. Acad. Sci. USA 75: 4037-4041.

Mobley, P., and P. Greengard (1985) Evidence for widespread effects of noradrenaline on axon terminals in the rat frontal cortex. Proc. Natl. Acad. Sci. USA 82: 945-947.

Mobley, W. C., A. Schenker, and E. M. Shooter (1976) Characterization and isolation of proteolytically modified nerve growth factor. Biochemistry 15: 5543-5551.

Navone, F., P. Greengard, and P. DeCamilli (1984) Synapsin I in nerve terminals: Selective association with small synaptic vesicles. Science 226: 1209-1211.

Nestler, E. J., and P. Greengard (1980) Dopamine and depolarizing 
agents regulate the state of phosphorylation of protein I in the mammalian superior cervical sympathetic ganglion. Proc. Natl. Acad. Sci. USA 77: 7479-7483.

Nestler, E. J., and P. Greengard (1982) Nerve impulses increase the phosphorylation state of protein I in rabbit superior cervical ganglion. Nature 296: 452-454.

Romano, C., R. A. Nichols, and P. Greengard (1984) Synapsin I in PC1 2 cells: Characterization, and effects of nerve growth factor. Soc. Neurosci. Abstr. 10: 1041.

Romano, C., R. A. Nichols, and P. Greengard (1987) Synapsin I in $\mathrm{PC} 12$ cells. II. Evidence for regulation by NGF of phosphorylation at a novel site. J. Neurosci. 7: 1300-1305.

Salton, S. R. J., M. L. Shelanski, and L. A. Greene (1983) Biochemical properties of the nerve growth factor-inducible large external (NILE) glycoprotein. J. Neurosci. 3: 2420-2430.

Tischler, A. S., and L. A. Greene (1978) Morphologic and cytoshem- ical properties of a clonal line of rat adrenal pheochromocytoma cells which respond to nerve growth factor. Lab. Invest. 39: 77-89.

Towbin, H., T. Staeheliu, and J. Gordon (1979) Electrophoretic transfer of proteins from polyacrylamide gels to nitrocellulose sheets: Procedure and some applications. Proc. Natl. Acad. Sci. USA 76: 43504354.

Tsou, K., and P. Greengard (1982) Regulation of phosphorylation of proteins $\mathrm{I}_{1} \mathrm{III}_{a}$, and $\mathrm{III}_{b}$ in rat neurohypophysis in vitro by electrical stimulation and by neuroactive agents. Proc. Natl. Acad. Sci. USA 79: 6075-6079.

Ueda, T., and P. Greengard (1977) Adenosine 3':5'-monophosphateregulated phosphoprotein system of neuronal membranes. I. Solubilization, purification, and some properties of an endogenous phosphoprotein. J. Biol. Chem. 252: 5155-5163.

Weston, J.A. (1970) The migration and differentiation of neural crest cells. Adv. Morphog. 8: 41-114. 